\title{
Lysine requirement for tambaqui juveniles
}

\section{Exigência de lisina para juvenis de tambaqui}

\author{
Janayra Cardoso Silva ${ }^{1 *}$; Marcos Antonio Delmondes Bomfim²; \\ Eduardo Arruda Teixeira Lanna ${ }^{3}$; Felipe Barbosa Ribeiro ${ }^{2}$; \\ Jefferson Costa de Siqueira ${ }^{2}$; Thalles José Rêgo de Sousa ${ }^{1}$; \\ Rafael Silva Marchão ${ }^{1}$; Daphinne Cardoso Nagib do Nascimento ${ }^{4}$
}

\begin{abstract}
The aim of this study was to determine the requirement for lysine in the diet of juvenile tambaqui (Colossoma macropomum). In total, 750 juvenile fish $(0.34 \pm 0.02 \mathrm{~g})$ were distributed in tanks arranged in a randomized block design with six treatments, five replications in two blocks, and 25 fish per unit, for $50 \mathrm{~d}$. Six levels of digestible lysine were tested $(1.30,1.48,1.66,1.84,2.02$, and $2.20 \%)$, in formulated diets based on the ideal protein concept. The performance, feed efficiency, daily deposition of protein and body fat, and nitrogen retention efficiency of the fish were evaluated. The consumption of rations and protein, specific growth rate, body composition, and deposition of body fat were not influenced by the lysine levels tested. The consumption of digestible lysine increased linearly and the efficiency of digestible lysine for weight gain decreased linearly with the increase in lysine levels. The levels of digestible lysine that optimized weight gain and body protein deposition were estimated at 1.73 and $1.78 \%$, respectively. The feed conversion and nitrogen retention efficiency were most improved at $1.66 \%$ and $1.84 \%$, respectively. The recommended level of dietary lysine for providing better weight gain and body protein deposition in juvenile tambaqui is $1.78 \%$, equivalent to $2.00 \%$ total lysine.
\end{abstract}

Key words: Body composition. Colossoma macropomum. Initial growth phase. Protein nutrition.

\section{Resumo}

Objetivou-se determinar a exigência de lisina nas rações para juvenis de tambaqui (Colossoma macropoтит). 750 peixes $(0,34 \pm 0,02 \mathrm{~g})$ foram distribuídos em tanques organizados em delineamento de blocos casualizados, com seis tratamentos, cinco repetições em dois blocos e vinte e cinco peixes por parcela, durante cinquenta dias. Foram testados seis níveis de lisina digestível $(1,30 ; 1,48 ; 1,60$; 1,$84 ; 2,02$; e $2,20 \%$ ), em dietas formuladas com base no conceito de proteína ideal. Avaliaram-se o desempenho, eficiência alimentar, deposições diárias de proteína e gordura corporais e a eficiência de retenção de nitrogênio. Os consumos de ração e de proteína, taxa de crescimento específico, composição corporal e deposição de gordura corporal não foram influenciados pelos níveis de lisina testados. O consumo de lisina digestível aumentou linearmente e a eficiência de lisina digestível para o ganho de peso reduziu de forma linear com a elevação dos níveis de lisina. O nível de lisina digestível da

\footnotetext{
1 Discentes, Programa de Pós-Graduação em Ciência Animal, Universidade Federal do Maranhão, UFMA, Campus IV Chapadinha, Chapadinha, MA, Brasil. E-mail: janayrasilva.c@gmail.com; talesrego@hotmail.com; rafaelmarchao@yahoo.com.br

2 Profs., Curso de Zootecnia, UFMA, Campus IV Chapadinha, Chapadinha, MA, Brasil. E-mail: madbomfim@yahoo.com.br; felipebribeiro@yahoo.com

3 Prof., Departamento de Zootecnia, Universidade Federal de Viçosa, UFV, Viçosa, MG, Brasil. E-mail: elanna@ufv.br

4 Pesquisador, Programa de Pós-Graduação em Ciência Animal, Universidade Federal do Piauí, UFPI, Campus Petrônio Portella, Teresina, PI, Brasil. E-mail: daphinnec@yahoo.com.br

* Author for correspondence
} 
ração que otimizou o ganho de peso e deposição de proteína corporal foi estimado em 1,73 e 1,78\%, respectivamente. A conversão alimentar e eficiência de retenção de nitrogênio melhoraram no nível de $1,66 \%$ e $1,84 \%$, respectivamente. A recomendação do nível de lisina digestível em rações para juvenis de tambaqui é de $1,78 \%$, equivalente a $2,00 \%$ de lisina total por proporcionar melhor ganho de peso e deposição de proteína corporal.

Palavras-chave: Colossoma macropomum. Composição corporal. Fase inicial. Nutrição proteica.

\section{Introduction}

The tambaqui (Colossoma macropum) is a species native to the Amazon region that has potential for zootechnical farming due to its productive and organoleptic characteristics (ARAUJO-LIMA and GOMES, 2005). On the other hand, there is a lack of information on its nutritional requirements, especially in relation to the normally limiting amino acids in feeding practices (DAIRIKI; SILVA, 2011; OLIVEIRA et al., 2013).

Fish, similarly to birds and mammals, do not have a dietary requirement for protein, but instead require a quantitative balance of essential and non-essential amino acids. Accordingly, a ration formulated based on crude protein may not meet the nutritional requirements for all amino acids. As a strategy to meet the amino acid requirements of the species, the ideal protein concept has been used in previous studies to formulate feed (TAKISHITA et al., 2009).

The ideal protein corresponds to an ideal amino acid balance, without excesses or deficits, that meets the requirements for maintenance and growth. The amino acid used as a reference to the profile of the ideal protein is lysine (BAKER; HAN, 1994; PARSONS; BAKER, 1994; FURUYA et al., 2005; BOMFIM et al., 2008).

Lysine is a reference amino acid used in the determination of the ideal protein standard because it is the most limiting in some protein sources alternative to fish meal, mainly in cereals (such as gluten), being found in higher concentrations in proteins of animal origin. In addition, the laboratory analysis of its levels in ingredients, rations, and tissues is more accessible, besides being an amino acid primarily directed to body protein deposition (BAKER; HAN, 1994; KIM; LALL, 2000; RODEHUTSCORD et al., 2000; FURUYA et al.,
2004; DAIRIKI et al., 2007; ABIMORAD et al., 2008; BRANDÃO et al., 2009; OVIE; EZE, 2013).

Given the lack of information regarding the requirement of lysine in tambaqui feed, this study was carried out to determine the requirement of lysine in the rations for juveniles of this species.

\section{Material and Methods}

The experiment was conducted in accordance with the ethical standards for animal research, after approval by the Ethics Committee on Animal Use of the Federal University of Maranhão (Protocol: $23115004063 / 2012$ - 95), and was carried out over $50 \mathrm{~d}$ at Laboratory of Food and Nutrition of Aquatic Organisms in the center of Agricultural and Environmental Sciences of the Federal University of Maranhão (UFMA), Chapadinha, Maranhão.

The experiment used 750 tambaqui, with an initial weight of $0.34 \pm 0.02 \mathrm{~g}$, in a randomized block design, consisting of six treatments with five replications in two blocks, and 25 fish per experimental unit.

The treatments consisted of six experimental isoproteic, isonenergetic, isocalcium, and isophosphorus rations with different levels of digestible lysine $(1.30,1.48,1.66,1.84,2.02$, and $2.20 \%$ ), formulated using the supplementation with amino acids technique based on the ideal protein concept. In the rations, the methionine plus cystine:lysine ratio, as well as the other amino acids:lysine ratios, were kept at least five percentage points above the values recommended by Souza (2014) for tambaqui, and estimated from the values of requirements for Nile tilapia (Oreochromis niloticus) proposed by the NRC (2011), respectively, in order to avoid the occurrence of another limiting amino acid for each level of supplementation of digestible lysine evaluated (Table 1). 
Table 1. Percentage and chemical composition of the experimental rations (natural matter).

\begin{tabular}{|c|c|c|c|c|c|c|}
\hline \multirow{2}{*}{ Ingredients $(\%)$} & \multicolumn{6}{|c|}{ Level of digestible lysine (\%) } \\
\hline & 1.30 & 1.48 & 1.66 & 1.84 & 2.02 & 2.20 \\
\hline Soy bran & 51.511 & 51.511 & 51.511 & 51.511 & 51.511 & 51.511 \\
\hline Corn & 34.830 & 34.830 & 34.830 & 34.830 & 34.830 & 34.830 \\
\hline Corn starch & 0.000 & 0.291 & 0.599 & 0.974 & 1.406 & 2.177 \\
\hline Soybean oil & 3.885 & 3.797 & 3.697 & 3.552 & 3.384 & 3.246 \\
\hline Lysine $\mathrm{HCl}(78.4 \%)$ & 0.000 & 0.230 & 0.460 & 0.690 & 0.920 & 1.150 \\
\hline DL-Methionine (99.0\%) & 0.194 & 0.322 & 0.450 & 0.579 & 0.707 & 0.835 \\
\hline L-Threonine (98.5\%) & 0.155 & 0.308 & 0.461 & 0.613 & 0.766 & 0.919 \\
\hline L-Tryptophan (98.0\%) & 0.000 & 0.044 & 0.090 & 0.136 & 0.182 & 0.228 \\
\hline L-Isoleucine (99.0\%) & 0.000 & 0.000 & 0.023 & 0.143 & 0.263 & 0.383 \\
\hline L-Valine $(96.5 \%)$ & 0.000 & 0.000 & 0.000 & 0.000 & 0.070 & 0.179 \\
\hline L-Arginine $(99.0 \%)$ & 0.000 & 0.000 & 0.000 & 0.000 & 0.004 & 0.162 \\
\hline L-Glutamic Acid (98.5\%) & 5.046 & 4.288 & 3.499 & 2.592 & 1.577 & 0.000 \\
\hline Dicalcium phosphate & 3.310 & 3.310 & 3.310 & 3.310 & 3.310 & 3.310 \\
\hline Vitamin and mineral premix ${ }^{5}$ & 0.500 & 0.500 & 0.500 & 0.500 & 0.500 & 0.500 \\
\hline Vitamin $\mathrm{C}^{4}$ & 0.050 & 0.050 & 0.050 & 0.050 & 0.050 & 0.050 \\
\hline Salt & 0.500 & 0.500 & 0.500 & 0.500 & 0.500 & 0.500 \\
\hline (Antioxidant BHT) & 0.020 & 0.020 & 0.020 & 0.020 & 0.020 & 0.020 \\
\hline \multicolumn{7}{|c|}{ Calculated composition $^{1}$} \\
\hline Crude protein (\%) & 29.14 & 29.14 & 29.14 & 29.14 & 29.14 & 29.14 \\
\hline Digestible protein $(\%)^{3}$ & 26.78 & 26.78 & 26.78 & 26.78 & 26.78 & 26.78 \\
\hline Digestible energy $\left(\mathrm{kcal} \mathrm{kg}^{-1}\right)^{3}$ & 3000.01 & 3000.00 & 3000.00 & 3000.00 & 3000.00 & 3000.01 \\
\hline Ether extract (\%) & 6.01 & 5.92 & 5.82 & 5.68 & 5.51 & 5.37 \\
\hline Crude fiber (\%) & 3.33 & 3.33 & 3.33 & 3.33 & 3.33 & 3.33 \\
\hline Total Ca (\%) & 0.95 & 0.95 & 0.95 & 0.95 & 0.95 & 0.95 \\
\hline $\mathrm{P}$ available $(\%)^{2}$ & 0.70 & 0.70 & 0.70 & 0.70 & 0.70 & 0.70 \\
\hline Total lysine $(\%)^{2}$ & 1.517 & 1.698 & 1.878 & 2.058 & 2.239 & 2.419 \\
\hline Digestible lysine $(\%)^{2}$ & 1.300 & 1.480 & 1.660 & 1.840 & 2.020 & 2.200 \\
\hline Digestible methionine. + cysteine $(\%)^{2}$ & 0.910 & 1.036 & 1.162 & 1.288 & 1.414 & 1.540 \\
\hline Digestible threonine $(\%)^{2}$ & 1.066 & 1.214 & 1.361 & 1.509 & 1.656 & 1.804 \\
\hline Digestible tryptophan $(\%)^{2}$ & 0.345 & 0.389 & 0.434 & 0.479 & 0.525 & 0.570 \\
\hline Digestible isoleucine $(\%)^{2}$ & 1.073 & 1.073 & 1.096 & 1.214 & 1.333 & 1.452 \\
\hline Digestible arginine $(\%)^{2}$ & 1.754 & 1.754 & 1.754 & 1.754 & 1.757 & 1.914 \\
\hline Digestible valine (\%) & 1.143 & 1.143 & 1.143 & 1.143 & 1.212 & 1.320 \\
\hline Digestible lysine/energy $\left(\mathrm{g} \mathrm{Mcal}^{-1}\right)$ & 0.433 & 0.493 & 0.553 & 0.613 & 0.673 & 0.733 \\
\hline
\end{tabular}

${ }^{1}$ Based on the values proposed by Rostagno et al. (2011);

${ }^{2}$ Based on the digestibility coefficients of industrial aminoacids proposed by Rostagno et al. (2011) and for amino acids and phosphorus availability for corn and soybean meal proposed by Furuya (2010);

${ }^{3}$ Based on the digestibility coefficients proposed by Furuya (2010) for Nile tilapia;

${ }^{4}$ Vitamin C: Calcium L-ascorbic acid 2-monophosphate, $42 \%$ of active ingredient;

${ }^{5}$ Vitamin and mineral supplement $\left(5 \mathrm{~kg} \mathrm{t}^{-1}\right)$, with guaranteed levels per kilogram of product: Total vitamins, 1,200,000 IU; vit. $\mathrm{D}_{3}$, 200,000 IU; vit. E, 1,200 mg; vit. $\mathrm{K}_{3}, 2,400 \mathrm{mg}$; vit. $\mathrm{B}_{1}, 4,800 \mathrm{mg}$; vit. $\mathrm{B}_{2}, 4,800 \mathrm{mg}$; vit. $\mathrm{B}_{6}, 4,800 \mathrm{mg}$; vit. $\mathrm{B}_{12}, 4,800 \mathrm{mg}$; folic acid, $1,200 \mathrm{mg}$; Ca pantothenate, $12,000 \mathrm{mg}$; vit. C, 48,000 mg; biotin, $48 \mathrm{mg}$; choline chloride, $108 \mathrm{~g}$; niacin, $24,000 \mathrm{mg}$; Fe, 50,000 mg; Cu, 3,000 mg; Mn, 20,000 mg; Zn, 30,000 mg; I, 100 mg; Co, 10 mg; Se, 100 mg. 
The fingerlings were kept in 30 polyethylene boxes, 12 of 1,000 L and 18 of $500 \mathrm{~L}$, with individual water supply, drainage, and aeration systems.

The water supply for the aquariums was derived from an artesian well. The water temperature was measured daily, at $7 \mathrm{~h} 30$ and $17 \mathrm{~h} 30$, with the help of a mercury bulb thermometer, graduated from 0 to $50{ }^{\circ} \mathrm{C}$. The monitoring of $\mathrm{pH}$, dissolved oxygen, and ammonia in the water was performed every $7 \mathrm{~d}$ with a $\mathrm{pH}$-meter, pulse oximeter, and commercial colorimetric kit to test for toxic ammonia, respectively.

The maximum and minimum temperatures remained at $26.1 \pm 0.64{ }^{\circ} \mathrm{C}$ and $24.2 \pm 0.76{ }^{\circ} \mathrm{C}$, respectively; the concentration of dissolved oxygen in the water was $7.63 \pm 0.70 \mathrm{ppm}$, while $\mathrm{pH}$ was $5.8 \pm 0.39$ and total ammonia was $\leq 1.00 \mathrm{ppm}$. The water quality parameters remained within the recommended standards for the breeding of the species (GOMES et al., 2010; MENDONÇA et al., 2012).

The ingredients of the experimental rations were mixed, moistened in water heated to about $50{ }^{\circ} \mathrm{C}$, and the mixture was pelleted using a meat grinder with $5 \mathrm{~mm}$ sieve (C.A.F. Meat grinder; model 98 STI). Then, the rations were dried in open air, crushed, and sieved, to attain pellets of around 3 $\mathrm{mm}$ in diameter.

The rations were offered daily in six meals (08h00, 10h00, 12h00, 14h00, 16h00, and 18h00). At every meal, the rations were offered in small quantities, with successive passes to apparent satiation, thus avoiding over- or underdelivering of feed. Cleaning of the boxes was performed daily by siphoning after measuring water temperature.

At the beginning of the experiment, 50 fish were stunned and euthanized in water with ice, and frozen for later determination of initial body composition. In the end, all fish in each box, after 24 hours of fasting, were stunned, euthanized, weighed, and frozen for determination of final body composition.

After thawing, the whole fish were pre-dried in an oven with forced air circulation, pre-degreased in glass containers using petroleum ether as solvent, milled in a ball mill and placed in containers for laboratory analysis. The samples were analyzed for body composition (moisture, crude protein, and lipids) according to the procedures described by Silva and Queiroz (2005). The laboratory analyses were performed in the Laboratory of Animal Nutrition at the Federal University of Maranhão (UFMA).

The following parameters were evaluated: survival rate (SR), feed consumption (FC), consumption of crude protein (CCP), consumption of digestible lysine (CDL), weight gain (WG), specific growth rate (SGR), feed conversion (FC), protein efficiency rate (PER), efficiency of digestible lysine for weight gain (ELW), chemical body composition (moisture, protein, and fat), rates of daily body protein (BPD) and fat deposition (BFD), and retention efficiency of nitrogen (NRE), according to the equations:

- $\operatorname{SR}(\%)=\frac{\text { final number of fish } \times 100}{\text { initial number of fish }}$

- $\quad \mathrm{FC}(\mathrm{g})=$ feed consumed during the experimental period

- $\mathrm{CCP}(\mathrm{g})=\frac{\text { consumption of feed }(\mathrm{g}) \times \text { level of crude proteins in feed }(\%)]}{100}$

- $\mathrm{CDL}(\mathrm{mg})=\frac{\text { [consumption of feed }(\mathrm{mg}) \times \text { level of digestible lysine in feed }(\%)]}{100}$ 
- $\quad \mathrm{WG}(\mathrm{g})$ = final mean weight $(\mathrm{g})$ - initial mean weight $(\mathrm{g})$

- $\operatorname{SGR}\left(\%\right.$ day $\left.^{-1}\right)=\frac{\{[\text { natural logarithm of final weight }(\mathrm{g})-\text { natural logarithm of initial weight }(\mathrm{g})] \times 100\}}{\text { experimental period (days) }}$

- $\quad \mathrm{FC}\left(\mathrm{g} \mathrm{g}^{-1}\right)=\frac{\text { consumption of feed }(\mathrm{g})}{\text { Weight gain }(\mathrm{g})}$

- $\quad \operatorname{PER}\left(\mathrm{g} \mathrm{g}^{-1}\right)=\frac{\text { weight gain }(\mathrm{g})}{\text { consumption of crude protein }(\mathrm{g})}$

- $\operatorname{BPD}\left(\mathrm{mg} \mathrm{day}^{-1}\right)=\frac{\{[\text { (final body protein, } \% \times \text { final weight, } \mathrm{mg})-(\text { initial body protein, } \% \times \text { initial weight, } \mathrm{mg})] / 100\}}{\text { Experimental period }(\text { days })}$

- $\operatorname{BFD}\left(\mathrm{mg} \mathrm{day}^{-1}\right)=\frac{\{[(\text { final body fat, } \% \times \text { final weight, } \mathrm{mg})-(\text { initial body fat, } \% \times \text { initial weight, } \mathrm{mg})] / 100\}}{\text { Experimental period }(\text { days })}$

- $\operatorname{NRE}(\%)=\frac{[\text { final body } \mathrm{N}(\%) \times \text { final weight }(\mathrm{g})]-[\text { initial body } \mathrm{N}(\%) \times \text { initial weight }(\mathrm{g})]}{(\text { feed consumption, } \mathrm{g} \times \text { level of } \mathrm{N} \text { in ration, } \%) / 100}$

The variables were subjected to analysis of variance with $5 \%$ significance. Variables that displayed significant effects of digestible lysine by variance analysis were subjected to linear and quadratic regressions. The discontinuous linear response plateau (LRP) model was also evaluated. The best fit model considered the value of significance $(P)$ and the $R^{2}$ (SQ the model/SQ treatment). In addition, variables were submitted to the model proposed by Baker et al. (2002) to estimate the intermediary requirement, which were obtained with the quadratic-plus-LRP models individually.

In variables where there was no significant fit $(P<0.10)$ to the regression models, the StudentNewman-Keuls (SNK) test was used to compare the means of each treatment. Statistical analyses were performed using SAS (2002) 9.0 software.

\section{Results and Discussion}

The rate of survival, feed consumption of crude protein, and specific growth rate were not influenced $(P>0.05)$ by the level of digestible lysine in the ration (Table 2). Given that the diets contained different levels of digestible lysine, the consumption of digestible lysine increased linearly $(P<0.05)$ with the increase in dietary lysine levels (Tables 2 and 3). These results indicate that the significant effects observed in other variables were caused by the difference in the consumption of digestible lysine, since it was the most limiting essential amino acid in all experimental rations. The lack of variation in feed intake may be associated with the fact that the diets were isoenergetic, as the energy level of the diet can influence fish intake (NRC, 2011). 
Table 2. The survival rate (SR), feed consumption (FC), consumption of crude protein (CCP), consumption of digestible lysine (CDL), weight gain (WG), specific growth rate (SGR), feed conversion (FC), protein efficiency rate (PER), and efficiency of digestible lysine for weight gain (ELW) of juvenile tambaqui, and a summary of the analysis of variance, depending on the level of digestible lysine in rations.

\begin{tabular}{cccccccccc}
\hline $\begin{array}{c}\text { Level of } \\
\text { digestible } \\
\text { lysine }(\%)\end{array}$ & $\begin{array}{c}\text { SR } \\
(\%)\end{array}$ & $\begin{array}{c}\text { FC } \\
(\mathrm{g})\end{array}$ & $\begin{array}{c}\text { CCP } \\
(\mathrm{g})\end{array}$ & $\begin{array}{c}\text { CDL } \\
(\mathrm{mg})\end{array}$ & $\begin{array}{c}\text { WG } \\
(\mathrm{g})\end{array}$ & $\begin{array}{c}\text { SGR } \\
\left(\% \mathrm{day}^{-1}\right)\end{array}$ & $\begin{array}{c}\text { FC } \\
\left(\mathrm{g} \mathrm{g}^{-1}\right)\end{array}$ & $\begin{array}{c}\text { TEP } \\
\left(\mathrm{g} \mathrm{g}^{-1}\right)\end{array}$ & $\begin{array}{c}\text { ELW } \\
\left(\mathrm{g} \mathrm{g}^{-1}\right)\end{array}$ \\
\hline 1.30 & 95.20 & 5.45 & 1.55 & 70.81 & 3.73 & 5.17 & $1.39^{\mathrm{a}}$ & $2.42^{\mathrm{b}}$ & 57.99 \\
1.48 & 96.80 & 6.09 & 1.73 & 90.12 & 4.52 & 5.28 & $1.38^{\mathrm{a}}$ & $2.60^{\mathrm{ab}}$ & 50.23 \\
1.66 & 94.40 & 5.81 & 1.66 & 96.38 & 5.33 & 5.56 & $1.14^{\mathrm{b}}$ & $3.34^{\mathrm{a}}$ & 57.35 \\
1.84 & 94.40 & 6.25 & 1.78 & 115.04 & 5.35 & 5.48 & $1.21^{\mathrm{ab}}$ & $2.99^{\mathrm{ab}}$ & 46.37 \\
2.02 & 98.40 & 5.80 & 1.43 & 117.17 & 4.59 & 5.30 & $1.25^{\mathrm{ab}}$ & $2.95^{\mathrm{ab}}$ & 39.34 \\
2.20 & 98.40 & 6.33 & 1.80 & 139.32 & 5.24 & 5.51 & $1.21^{\mathrm{ab}}$ & $2.91^{\mathrm{ab}}$ & 37.76 \\
\hline$P>F^{1}$ & 0.9999 & 0.2820 & 0.0601 & 0.0001 & 0.0113 & 0.2094 & 0.0049 & 0.0323 & 0.0001 \\
\hline $\mathrm{CV}(\%)$ & 4.87 & 10.77 & 12.35 & 10.49 & 15.28 & 5.20 & 8.21 & 11.93 & 14.46 \\
\hline
\end{tabular}

CV: Coefficient of variation (\%);

$P>F$ : Significance of " $F$ " test of analysis of variance;

Means in the column followed by the same letters do not differ by the SNK test $(\mathrm{P}>0.05)$.

Table 3. Adjusted regression equations, $P$ values, coefficients of determination and values of the requirement for the variables, consumption of digestible lysine (CDL), weight gain (WG), and efficiency of digestible lysine for weight gain (ELW) of juvenile tambaqui as a function of levels of digestible lysine in rations.

\begin{tabular}{lccccc}
\hline Variable & Model & Equation & $P>F$ & $\mathrm{R}^{2}$ & Requirement (\%) \\
\hline CDL $(\mathrm{mg})$ & Linear & $\mathrm{CLD}=-18.0742+70.2184 \mathrm{Lys}$ & 0.0001 & 0.97 & ----- \\
WG $(\mathrm{g})$ & Linear & $\mathrm{GP}=2.6313+1.2352 \mathrm{Lys}$ & 0.0946 & 0.42 & ---- \\
WG $(\mathrm{g})$ & Quadratic & $\mathrm{GP}=-8.8618+14.7885 \mathrm{Lys}-3.8724 \mathrm{Lys}^{2}$ & 0.0918 & 0.71 & 1.91 \\
WG $(\mathrm{g})$ & LRP & $\mathrm{GP}=5.1280-4.3889(1.6190-\mathrm{Lys})$ & 0.0630 & 0.81 & 1.62 \\
WG $(\mathrm{g})$ & Quadratic + LRP & $5.1280=-8.8618+14.7885$ Lys $-3.8724 \mathrm{Lys}^{2}$ & - & - & 1.73 \\
ELW $\left(\mathrm{g} \mathrm{g}^{-1}\right)$ & Linear & $\mathrm{ELG}=88.3967-22.9857$ Lys & 0.0044 & 0.80 & ----- \\
\hline
\end{tabular}

$P>F$ : Significance of "F" analysis of variance test.

The weight gain displayed a quadratic effect $(\mathrm{P}<0.10)$ as a function of digestible lysine in feed rations, estimating the requirement at $1.910 \%$. However, the LRP model was the best fit $(P<0.07)$ to the data, estimated at $1.619 \%$ digestible lysine, from which there was a plateau (Tables 2 and 3 ).

It should be emphasized that the quadratic model can provide an overestimation in requirement, because the model assumes bilateral symmetry of the response to increasing nutrient, since the quadratic model describes the drop in gain in the same intensity as the loss in gain. Furthermore, the quadratic function is very sensitive to the difference between the levels studied, tending to estimate the optimal values within the range of levels (EUCLYDES; ROSTAGNO, 2002). Although it has a good statistical fit, the LRP model, in turn, does not consider the physiological aspects of the animal and the law of diminishing returns; therefore, in many cases, it underestimates the optimal level, since it does not consider the increases that could justify additional improvements in performance 
(PACK, 1996; PACK et al., 2003; SAKOMURA; ROSTAGNO, 2007; SIQUEIRA et al., 2009).

Thus, it is possible to estimate the level of lysine in an intermediate form obtained with the LRP plus quadratic models individually, as a way to circumvent the criticisms of these models. According to Baker et al. (2002), the value of the first intersection is an excellent way of representing the requirements, because it is an objective value. The level of digestible lysine in the diet estimated to optimize weight gain, corresponding to the first intersection of the quadratic equation with the plateau estimated by the LRP model, was $1.73 \%$ (Figure 1).

The results for the weight gain of fish fed with diets containing less than $1.73 \%$ of digestible lysine demonstrate that the use of levels below the requirement restricts animal growth, probably due to the reduction in the formation of lean tissue. This is because lysine is an essential amino acid found in higher concentrations in the carcass than others, and is used almost exclusively for protein synthesis
(FURUYA et al., 2005; BOMFIM et al., 2010; NRC, 2011; BOMFIM, 2013).

Lysine requirements for Nile tilapia show different results than those estimated in this study to optimize weight gain $(1.73 \%)$. It was higher than those determined by Furuya et al. (2004), for fish in the 5.34 to $77.26 \mathrm{~g}$ stage, which estimated the lysine level at $1.42 \%$; by Furuya et al. (2013) for fish in the 87 to $226 \mathrm{~g}$ stage, fed diets balanced for arginine:lysine ratio, which estimated the requirement to be $1.31 \%$ digestible lysine; and by Furuya et al. (2006) with juveniles (5.72 to 35.05 $\mathrm{g}$ ), which determined the requirement to be $1.56 \%$ digestible lysine. On the other hand, the result of the present study was similar to that determined by Bomfim et al. (2010), working with fingerlings $(1.12 \mathrm{~g})$, which estimated $1.70 \%$ digestible lysine as the minimum level to obtain the optimum weight gain; and was lower than that found for Nile tilapia fingerlings ( $0.98 \mathrm{~g}$ ) by Takishita et al. (2009), who estimated the requirement to be $2.17 \%$ digestible lysine, both using the ideal protein concept in the formulation of experimental feed.

Figure 1. A graphical representation of weight gain for tambaqui juveniles as a function of digestible lysine levels in rations.

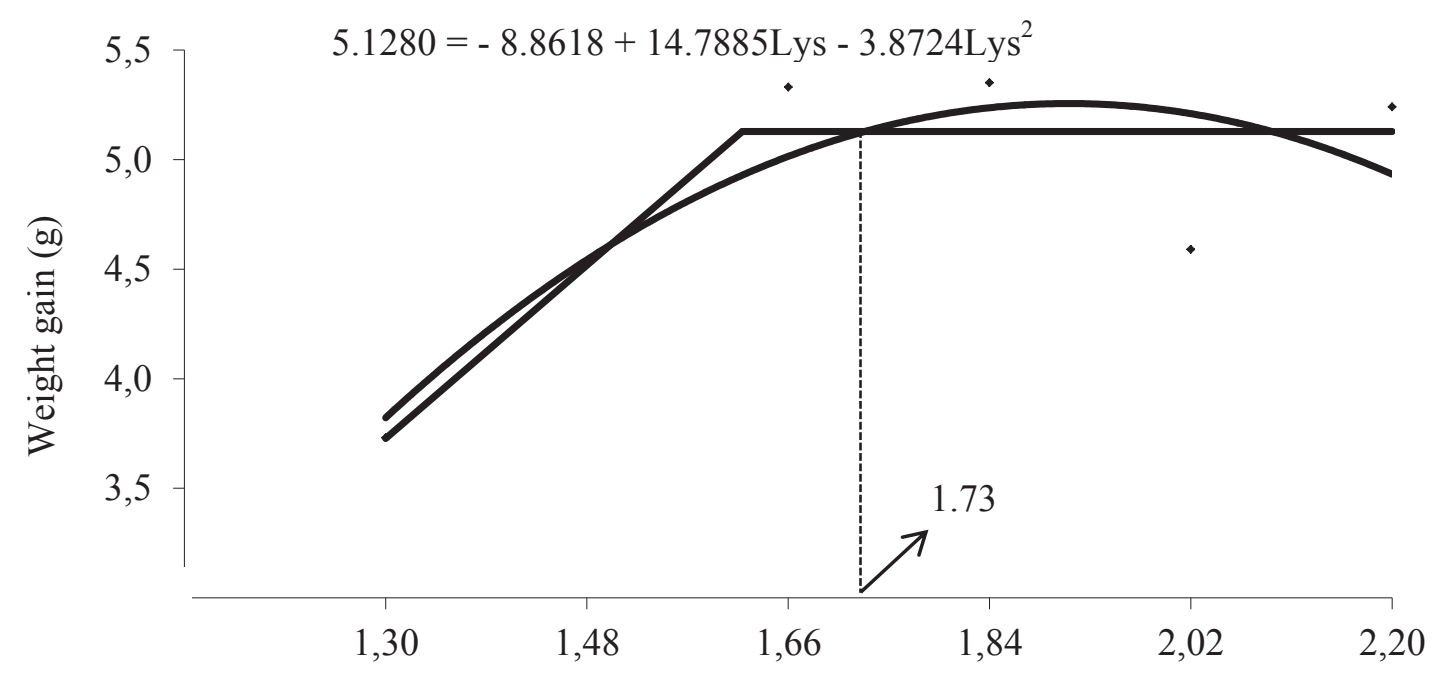

Digestible lysine (\%) 
For pacu (Piaractus mesopotamicus), an omnivorous species with morphometric and ecological characteristics similar to tambaqui, fed diets with different levels of lysine using the ideal protein concept at the 8.66 to $49.18 \mathrm{~g}$ stage, the dietary requirement to optimize weight gain was $1.64 \%$ digestible lysine (ABIMORAD et al., 2010), similar to that estimated in this study using the LRP model.

Besides the statistical criterion for the interpretation of the results (linear, quadratic, exponential, LRP, models, or means test), the level of energy used in the experimental feed can also influence the value of estimated requirement for a same species, since it directly affects the consumption of feed and, consequently, in the amount of amino acids consumed per unit of gain and its use for protein deposition. In addition, a deficiency in any one of the essential amino acids in the experimental feed may limit the synthesis of protein at higher lysine levels and, consequently, underestimate the lysine requirement obtained (SAKOMURA; ROSTAGNO, 2007; SIQUEIRA et al., 2009; BOMFIM et al., 2010).

The improvement in weight gain, together with the similar consumption of feed, resulted in an improved feed conversion $(P<0.05)$ as a function of an increase in digestible lysine in the feed. However, there was no fit $(P>0.10)$ for any of the regression models evaluated. Based on the SNK test, a level of $1.66 \%$ digestible lysine presented better results compared to lower levels, without variation compared to higher levels, and is therefore recommended for this variable (Table 2). It should be emphasized that according to Sampaio (2007), the quantitative nature of the treatments employed suggests the study of models, however, this procedure alone does not replace the comparison of means.

The improvement in feed conversion, especially in terms of similar energy and feed consumption, indicates that there was a higher efficiency of protein utilization for the formation of lean tissue; this includes a higher percentage of water in its composition (BOMFIM et al., 2010).

In a study on juvenile Nile tilapia, Furuya et al. (2006), observed an improvement in feed conversion of fish fed with a diet until the estimated level of $1.44 \%$ of digestible lysine, a lower result than the value observed in this study. Abimorad et al. (2010), in an experiment with pacus (8.66 to $49.18 \mathrm{~g}$ ), identified $1.75 \%$ digestible lysine for better feed conversion, which is a higher value than that found in the present study. On the other hand, in studies conducted by Bomfim et al. (2010), and Takishita et al. (2009), with Nile tilapia fingerlings, the increase in digestible lysine in feed provided a linear improvement in feed conversion.

The protein efficiency rate displayed a variation $(P<0.05)$ according to the levels of digestible lysine. However, there was no fit $(P>0.10)$ for any of the regression models evaluated. Based on the SNK test, $1.66 \%$ of digestible lysine showed better results compared to the lowest level tested, without variation in relation to other levels (Table 2). The efficiency of digestible lysine for weight gain deteriorated linearly $(P<0.01)$ with an increase in digestible lysine in feed (Tables 2 and 3).

The protein efficiency rate is influenced by the protein:energy ratio of the feed, as the energy level directly influences feed consumption and, consequently, the availability of dietary protein to meet the nutritional requirements for maintenance and body protein deposition (MATHIS et al., 2003; OISHI et al., 2010). In this case, as the rations were isoproteic and isoenergetic (same protein:energy ratio), this gain is probably due to the improvement of the biological value of the protein (amino acids) balance provided by raising the level of digestible lysine (digestible lysine:digestible energy ratio), since there was no other essential amino acid that limited the potential use of each level of lysine evaluated. This suggests that an improvement in the rate of body protein deposition and nitrogen retention 
efficiency was observed in this study (BOISEN, 2003; TAKISHITA et al., 2009; BOMFIM et al., 2010).

Gonçalves et al. (2009), highlighted that high levels of digestible lysine supplementation in diets with low protein levels do not provide the same response, highlighting the importance of lysine in balance with other amino acids. Furthermore, the adequate balancing of amino acids in the diet, as well as the use of moderate levels of synthetic amino acids and short feeding intervals can maintain a more stable plasma concentration of amino acids. This optimizes the capacity/velocity of protein synthesis by specialized tissues, increasing the efficiency of nitrogen retention and significantly reducing the excretion of nitrogen into the environment (TENGJAROENKUL et al., 2000; BOMFIM et al., 2008).
The body composition (moisture, protein, and fat) of fish and the deposition of body fat did not vary $(\mathrm{P}>0.05)$ with the variation in digestible lysine of the feed (Table 4).

The increase in digestible lysine in feed provided a quadratic effect on the body protein deposition, $(P$ $<0.10$ ), increasing this variable until the estimated level of $1.948 \%$. Despite the quadratic increase, the LRP model was the best fit $(P<0.09)$ to the data, estimating that there was a plateau at the $1.683 \%$ digestible lysine level (Tables 4 and 5). Using the first intersection of the quadratic equation with the plateau obtained by the LRP equation, the level of digestible lysine of ration estimated for this variable was $1.78 \%$ (Table 5, Figure 2). For the efficiency of nitrogen retention, the LRP model provided a better fit $(P<0.10)$ to the data, estimated that there was a plateau at the $1.58 \%$ digestible lysine level (Tables 4 and 5).

Table 4. Contents of body moisture (MC), fat (FC), and protein (PC); deposition of body protein (DBP) and body fat (DBF); and nitrogen retention efficiency (NRE) of juvenile tambaqui, and a summary of the analysis of variance, as a function of the digestible lysine levels in rations.

\begin{tabular}{ccccccc}
\hline \multirow{2}{*}{$\begin{array}{c}\text { Level of digestible } \\
\text { lysine (\%) }\end{array}$} & $\begin{array}{c}\text { MC } \\
(\%)\end{array}$ & $\begin{array}{c}\text { FC } \\
(\%)\end{array}$ & $\begin{array}{c}\text { PC } \\
(\%)\end{array}$ & $\begin{array}{c}\text { DGC } \\
\left(\mathrm{mg} \mathrm{day}^{-1}\right)\end{array}$ & $\begin{array}{c}\text { DBP } \\
\left(\mathrm{mg} \mathrm{day}^{-1}\right)\end{array}$ & $\begin{array}{c}\text { NRE } \\
(\%)\end{array}$ \\
\hline Initial & 75.89 & 4.47 & 14.87 & - & - & - \\
\hline 1.30 & 78.83 & 7.69 & 10.70 & 6.02 & 7.62 & 24.94 \\
1.48 & 76.62 & 8.06 & 11.58 & 7.63 & 10.12 & 29.31 \\
1.66 & 78.10 & 8.80 & 10.22 & 9.95 & 10.54 & 32.47 \\
1.84 & 79.22 & 5.95 & 11.36 & 6.71 & 12.01 & 33.53 \\
2.02 & 79.07 & 6.62 & 10.81 & 6.53 & 9.67 & 29.49 \\
2.20 & 78.31 & 7.19 & 11.20 & 7.73 & 11.51 & 32.02 \\
\hline$P>F$ & 0.0539 & 0.0887 & 0.1165 & 0.0534 & 0.0138 & 0.0324 \\
\hline CV $(\%)$ & 1.70 & 20.86 & 7.12 & 26.20 & 17.51 & 13.31 \\
\hline
\end{tabular}

$\mathrm{CV}$ : Coefficient of variation;

$P>F$ : Significance of " $F$ " test of analysis of variance. 
Table 5. Adjusted regression equations, coefficients of determination, and values of the requirement for the body protein deposition (DBP) and nitrogen retention efficiency (NRE) variables of juvenile tambaqui as a function of digestible lysine levels in rations.

\begin{tabular}{lccccc}
\hline Variable & Model & Equation & $P>F$ & $\mathrm{R}^{2}$ & $\begin{array}{c}\text { Requirement } \\
(\%)\end{array}$ \\
\hline DBP $\left(\mathrm{mg} \mathrm{day}^{-1}\right)$ & Linear & $\mathrm{DPC}=4.87333+3.0743$ Lys & 0.0707 & 0.45 & ---- \\
DBP $\left(\mathrm{mg} \mathrm{day}^{-1}\right)$ & Quadratic & $\mathrm{DPC}=-18.2046+30.2888$ Lys $-7.7756 \mathrm{Lys}^{2}$ & 0.0928 & 0.65 & 1.95 \\
DBP $\left(\mathrm{mg} \mathrm{day}^{-1}\right)$ & LRP & $\mathrm{DPC}=11.0640-7.9999(1.6827-\mathrm{Lys})$ & 0.0821 & 0.68 & 1.68 \\
DBP $\left(\mathrm{mg} \mathrm{day}^{-1}\right)$ & Quadratic + LRP & $11.0640=-18.2046+30.2888$ Lys -7.7756 Lys $^{2}$ & - & - & 1.78 \\
NRE $(\%)$ & LRP & $\mathrm{ERN}=31.8775-24.278(1.58-$ Lys $)$ & 0.0774 & 0.81 & 1.58 \\
\hline
\end{tabular}

$P>F$ : Significance of $\mathrm{F}$ analysis of variance test.

Based on the results obtained to optimize the weight gain and protein deposition, the recommended level of digestible lysine in the diet of tambaqui fingerlings is $1.78 \%$, equivalent to $2.00 \%$ total lysine. These percentages are higher than the $1.60 \%$ of digestible lysine recommended for Nile tilapia by the NRC (2011) and the recommended level in the
Brazilian table for the nutrition of tilapias (1.53\% of digestible lysine). However, it approaches the value of $1.70 \%$ digestible lysine recommended by Bomfim et al. (2010) and is lower than the $2.12 \%$ calculated by Takishita et al. (2009) in diets for Nile tilapia fingerlings, in which they also used the ideal protein concept to formulate the experimental rations.

Figure 2. Graphical representation of body protein deposition for tambaqui juveniles, depending on the levels of digestible lysine in rations.

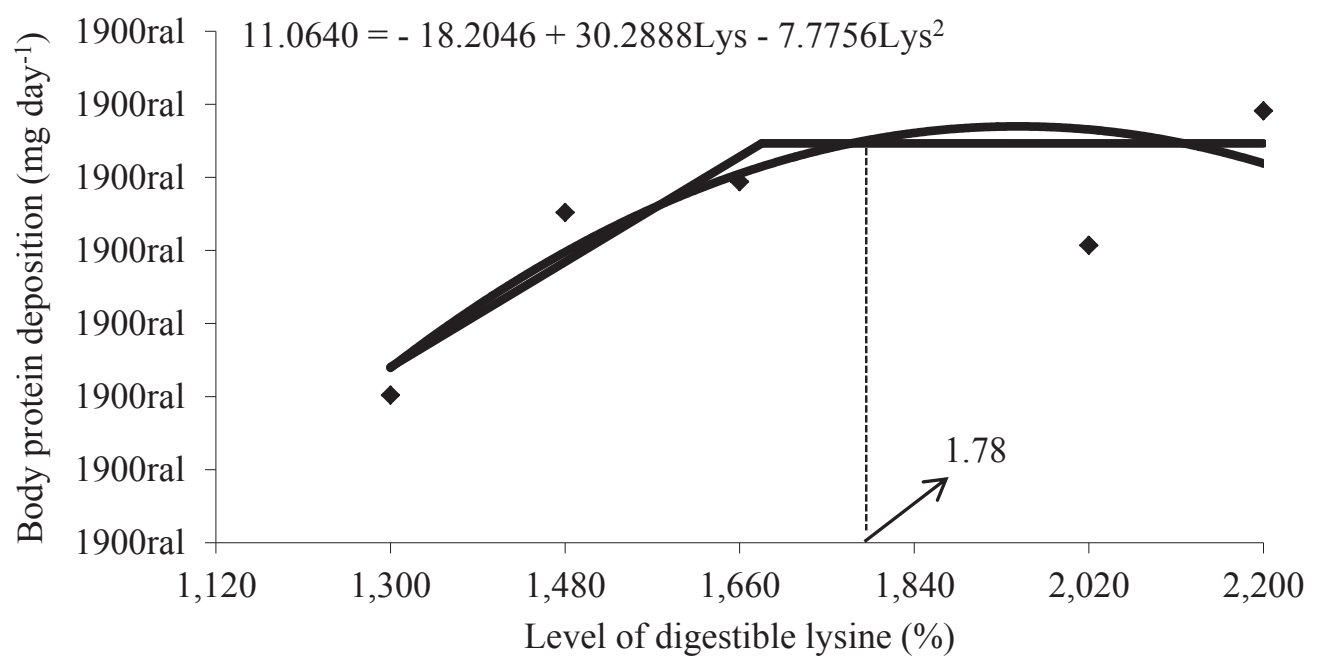

\section{Conclusion}

The recommended level of digestible lysine in the diet of tambaqui fingerlings is $1.78 \%$, equivalent to $2.00 \%$ total lysine, for providing increased weight gain and body protein deposition.

\section{Acknowledgments}

To the Fundação de Amparo à Pesquisa e ao Desenvolvimento Científico e Tecnológico do Maranhão (FAPEMA), for financing the project and providing the grant. 


\section{References}

ABIMORAD, E. G.; FAVERO, G. C.; SQUASSONI, G. H.; CARNEIRO, D. Dietary digestible lysine requirement and essential amino acid to lysine ratio for pacu Piaractus mesopotamicus. Aquaculture Nutrition, Oxford, v. 16, n. 4, p. $370-377,2010$.

ABIMORAD, E. G.; SQUASSONI, G. H.; CARNEIRO, D. J. Apparent digestibility of protein, energy, and amino acids in some selected feed ingredients for pacu Piaractus mesopotamicus. Aquaculture, Amsterdam, v. 14, n. 4, p. 374-380, 2008.

ARAUJO-LIMA, C. A. R. M.; GOMES, L. C. Tambaqui (Colossoma macropomum). In. BALDISSEROTTO, B.; GOMES, L. C. (Ed.). Espécies nativas para piscicultura no Brasil. Santa Maria: Ed. da UFSM, 2005. p. 175-193.

BAKER, D. H.; HAN, Y. Ideal amino acid profile for chicks during the first three weeks posthatching. Poultry Science, Champaign, v. 73, n. 1, p. 1441-1447, 1994.

BAKER, D. H.; BATAL, A. B.; PARR, T. M.; AUGSPURGER, N. R.; PARSONS, C. M. Ideal ration (relative to lysine) of tryptophan, threonine, isoleucine and valine for chicks during the second and third weeks posthatch. Poultry Science, v. 81, n. 4, p. 485-494, 2002.

BOISEN, S. Ideal dietary amino acid profiles for pigs. In: D'MELLO, J. P. F. (Ed.). Amino acids in animal nutrition. [S.1.]: CAB Publishing, 2003. p. 157-168.

BOMFIM, M. A. D.; LANNA, E. A. T.; DONZELLE, J. L.; ABREU, M. L. T.; RIBEIRO, F. B.; QUADROS, M. Redução de proteína bruta com suplementação de aminoácidos, com base no conceito de proteína ideal, em rações para alevinos de tilápia-do-Nilo. Revista Brasileira de Zootecnia, Viçosa, MG, v. 37, n. 10, p. 1713-1720, 2008.

BOMFIM, M. A. D.; LANNA, E. A. T.; DONZELLE, J. L.; QUADROS, M.; RIBEIRO, F. B.; SOUSA, M. P. Níveis de lisina, com base no conceito de proteína ideal, em rações para alevinos de tilápia-do-Nilo. Revista Brasileira de Zootecnia, Viçosa, MG, v. 39, n. 1, p. 1-8, 2010.

BOMFIM, M. A. D. Estratégias nutricionais para redução das excreções de nitrogênio e fósforo nos sistemas de produção de peixes no Nordeste: sustentabilidade ambiental e aumento da produtividade. Revista Cientifica de Produção Animal, Areia, PB v. 15, n. 2, p. 122-140, 2013.

BRANDÃO, L. V.; PEREIRA-FILHO, M.; GUIMARÃES, S. F.; FONSECA, F. A. L. da. Suplementação de metionina e/ou lisina em rações para juvenis de tambaqui (Colossoma macropomum Cuvier,
1818). ACTA Amazonica, Manaus, v. 39, n. 3, p. 675-680, 2009.

DAIRIKI, J. K.; DIAS, C. T. S.; CYRINO, J. E. P. Lysine requirements of large mouth bass, Micropterus salmoides: a comparison of methods of analysis of doseresponse trials data. Journal of Applied Aquaculture, Philadelphia, v. 19, n. 4, p. 1-27, 2007.

DAIRIKI, J. K.; SILVA, T. B. A. Revisão de literatura: exigências nutricionais do tambaqui - compilação de trabalhos, formulação de ração adequada e desafios futuros. Manaus: EMBRAPA Amazônia Ocidental, 2011. 44 p. (EMBRAPA Amazônia Ocidental. Document, 91).

EUCLYDES, R. F.; ROSTAGNO, H. S. Planejamento experimental em avicultura e interpretação de resultados. In: CONFERÊNCIA APINCO DE CIÊNCIA E TECNOLOGIA AVÍCOLAS, 2002, Campinas. Anais... Campinas: Fundação Apinco de Ciência e Tecnologia Avícolas, 2002. p. 117-133.

FURUYA, W. M. Tabelas brasileiras para nutrição de tilápias. Toledo: GFM, 2010. 100 p.

FURUYA, W. M.; BOTARO, D.; MACEDO, R. M. G.; SANTOS, V. G.; SILVA, L. C. R.; SIlVA T. C.; FURUYA, V. R. B.; SALES, P. J. P. Aplicação do conceito de proteína ideal para redução dos níveis de proteína em dietas para tilapia-do-Nilo (Oreochromis niloticus). Revista Brasileira de Zootecnia, Viçosa, MG, v. 3, n. 5, p. 1433-1441, 2005.

FURUYA, W. M.; MICHELATO, M.; GRACIANO, T. S.; VIDAL, L. V. O.; XAVIER, T. O.; FURUYA, V. R. B.; MOURA, L. B. Exigência de lisina digestível para a tilápia do Nilo de 87 a $226 \mathrm{~g}$ alimentada com dietas balanceadas para a relação arginina:lisina. Semina: Ciências Agrárias, Londrina, v. 34, n. 4, p. 1945-1954, 2013.

FURUYA, W. M.; PEZZATO, L. E.; BARROS, M. M.; PEZZATO, A. C.; FURUYA, V. R.; MIRANDA, E. C. Use of ideal protein concept for precision formulation of amino acidlevels in fish-meal-free diets for juvenile Nile tilapia (Oreochromis niloticus L.). Aquaculture Research, Chicester, v. 35, n. 12, p. 1110-1116, 2004.

FURUYA, W. M.; SANTOS, V. G.; SILVA, L. C. R.; FURUYA, V. R. B. Exigência de lisina digestível para juvenis de tilápia-do-Nilo. Revista Brasileira de Zootecnia, Viçosa, MG, v. 35, n. 3, p. 937-942, 2006.

GOMES, L. C.; SIMÕES, L. N.; ARAÚJO-LIMA, C. A. R. M. Tambaqui (Colossoma macropomum). In: BALDISSEROTTO, B.; GOMES, L. C. (Org.). Espécies nativas para piscicultura no Brasil. 2. ed. Santa Maria: Editora UFSM, 2010. p. 175-204. 
GONÇALVES, G. S.; PEZZATO, L. E.; BARROS, M. M.; TACHIBANA, L.; SANTA ROSA, M. J.; GUIMARÃES, I. G. Relação lisina digestível: proteína digestível em rações para tilápias-do-nilo. Revista Brasileira de Zootecnia, Viçosa, MG, v. 38, n. 12, p. 2299-2305, 2009.

KIM, J. D.; LALL, S. P. Amino acid composition of whole body tissue of Atlantic halibut (Hippoglossus hippoglossus), yellow-tail flounder (Pleuronectes ferruginea) and Japanese flounder (Paralichthyus olivaceus). Aquaculture, Amsterdam, v. 187, n. 3-4, p. 367-373, 2000.

MATHIS, N.; FEIDT, C.; BRUN-BELLUT, J. Influence of protein/ energy ratio on carcass quality during the growing period of Eurasian perch (Perca fluviatilis). Aquaculture, Amsterdam, v. 217, n. 1-4, p. 453-464, 2003.

MENDONÇA, P. P.; COSTA, P. C.; POLESE, M. F.; VIDAL JÚNIOR, M. V.; ANDRADE, D. R. Efeito da suplementação de fitase na alimentação de juvenis de tambaqui (Colossoma macropomum). Archivos de Zootecnia, Cordoba, v. 61, n. 235, p. 437-448, 2012.

NATIONAL RESEARCH COUNCIL - NRC. Nutrient requirements of fish and shrimp. Washington: National Academy Press, 2011. 360 p.

OISHI, C. A.; NWANNA, L. C.; PEREIRA FILHO, M. Optimum dietary protein requirement for Amazonian Tambaqui, Colossoma macropomum Cuvier, 1818, fed fish meal free diets. Acta Amazonica, Manaus, v. 40, n. 4, p. 757-762, 2010.

OLIVEIRA, A. C. B.; MIRANDA, E.; CORREA, R. Exigências nutricionais e alimentação do tambaqui. In: FRACALOSSI, D. M.; CYRINO, J. E. P. Nutrição e alimentação de espécies de interesse para a aquicultura brasileira. Florianópolis: Aquabio, 2013. p. 231-240.

OVIE, S. O.; EZE, S. S. Lysine requirement and its effect on the body composition of Oreochromis niloticus fingerlings. Journal of Fisheries and Aquatic Science, New Bussa, v. 8, n. 1, p. 94-100, 2013.

PACK, M. Models used to estimate nutrient requirements with emphasisin economic aspects. In: SIMPÓSIO INTERNACIONAL SOBREEXIGÊNCIAS NUTRICIONAIS DE AVES E SUÍNOS, 1996, Viçosa, MG. Anais... Viçosa, MG: Universidade Federal de Viçosa, 1996. p. 43-54.

PACK, M.; HOEHLER, D.; LEMME, A. Economic assessment of amino acid responses in growing poultry. In: D'MELLO, J. P. F. (Ed.). Amino acids in animal cutrition. Cambridge: CABI Publishing, 2003. p. 459483.
PARSONS, C. M.; BAKER, D. H. The concept and use of ideal proteins in the feeding of no ruminants. In: REUNIÃO ANUAL DA SOCIEDADE BRASILEIRA DE ZOOTECNIA, 31., 1994, Maringá. Anais... Maringá: SBZ, 1994. p. 120-128.

RODEHUTSCORD, M.; BORCHERT, F.; GREGUS, K.; PFEFFER, E. Availability and utilization of free lysine in rainbow trout Oncorhynchus mykiss. 1. Effect of dietary crude protein level. Aquaculture, Amsterdam, v. 187, n. 1-2, p. 163-176, 2000.

ROSTAGNO, H. S.; ALBINO, L. F. T.; DONZELE, J. L.; GOMES, P. C.; OLIVEIRA, R. F.; LOPES, D. C.; FERREIRA, A. S.; BARRETO, S. L. T.; EUCLIDES, R. F. Tabelas brasileiras para aves e suínos: composição de alimentos e exigências nutricionais. 3. ed. Viçosa, MG: UFV - Departamento de Zootecnia 2011. 252 p.

SAKOMURA, N. K.; ROSTAGNO, H. S. Métodos de pesquisa em nutrição de monogástricos. Jaboticabal: FUNEP, 2007. 283 p.

SAMPAIO, I. B. M. Estatística aplicada à experimentação animal. 3. ed. Belo Horizonte: FEPMVZ, 2007. v. 1, 264 p.

SILVA, D. J.; QUEIROZ, A. C. Análise de alimentos: métodos químicos e biológicos. 3. ed. Viçosa: MG: Editora UFV, 2005.

SIQUEIRA, J. C.; SAKOMURA, N. K.; NASCIMENTO, D. C. N.; FERNANDES, J. B. K. Modelos matemáticos para estimar as exigências de lisina digestível para aves de corte ISA Label. Revista Brasileira de Zootecnia, Viçosa, MG, v. 38, n. 9, p. 1732-1737, 2009.

SOUZA, F. O. Relação da Metionina mais cistina com a lisina em rações para alevinos de tambaqui (Colossoma macromum). 2014. Dissertação (Mestrado em Ciência Animal) - Universidade Federal do Maranhão, Chapadinha.

STATISTICAL ANALYSIS SYSTEM - SAS. SAS user's guide: statistics. 5. ed. Cary: SAS Institute, p. 956, 2002.

TAKISHITA, S. S.; LANNA, E. A. T.; DONZELE, J. L.; BOMFIM, M. A. D.; MOISÉS QUADROS, M.; SOUSA, M. P. Níveis de lisina digestível em rações para alevinos de tilápia-do-Nilo. Revista Brasileira de Zootecnia, Viçosa, MG, v. 38, n. 11, p. 2099-2105, 2009.

TENGJAROENKUL, B.; SMITH, B. J.; CACECI, T.; SMITH, S. A. Distribution of intestinal enzyme activities along the intestinal tract of cultured Nile tilapia, Oreochromis niloticus L. Aquaculture, Amsterdam, v. 182, n. 3-4, p. 317-327, 2000. 